\title{
Editorial:
}

\section{Experiences That Lead to Growth for Educators and Learners}

\author{
Julian Kitchen \\ Editor \\ Brock University
}

When teachers are responsive to students and "the situations in which interaction takes place" (Dewey, 1938, p. 45), they foster "experiences that lead to growth" (Dewey, 1938, p. 40). Dewey's words convey the essence of education as a discipline. The commonplace of education - teacher, learner, curriculum and milieu (Schwab, 1970) - exist in all schools, but the experience is educative only to the degree that these commonplaces interact to spark learning.

The authors of the articles in this issue of Brock Education all puzzle over the experiences of teachers and/or learners. In each case, their aim is to improve practice and, through this, contribute to a better world.

Some focus on teachers (often themselves), while others centre their work on the learner. Sometimes there is consderable overlap between the two. The venues range from elementary classrooms to professional development to graduate school. Some are intimate studies-e.g., ethnographic, narrative inquiry, and self-study — while others stand back from the experiencee.g., questionnaires and interviews. All ask probing questions about the teaching and learning experience. All are worthy of your attention.

Tara-Lynn Scheffel, in "Individual Paths to Literacy Engagement: Three Portraits," is interested in elementary school learners. In her ethnographic case study, she explores the literacy engagement of three very different second grade students. From these cases, she identifies four filters through which we can perceive individual literacy engagement. When educators better understand a range of student paths to literacy, they are more apt to engage each student.

While Jane P. Preston is very interested in the experiences of learners, her study begins with her belief that spirituality should have an important place in schooling. In "Fostering the Learner Spirituality of Students: A Teaching Narrative," she explores how this was lived out in a middle school classroom. She shares with Scheffel a deep respect for students and the importance of inquiring into how they experience education.

Hilary Brown, like Preston, writes a very personal and personally revealing account of a teacher passionately committed to transforming the learning of her students. "In Order to Be You Have to $B e$ : Modeling a Constructivist Approach for Teacher Candidates" makes explicit the challenges Brown faced while seeking to actively engage teacher candidates in constructivist learning. Through self-study, she honestly discusses struggle to maintain her approach despite a high level of resistance from her class. This is a powerful story of practicing what we preach!

In "Building Community in Triads Involved in Science Teacher Education: An Innovative Professional Development Model," Todd Campbell studies his practice as a teacher 
educator. He examines the use of triad models in a course offered to pre-service and in-service teachers. Whereas Brown's teaching was front-and-centre in her study, Campbell stands back from the learning strategy he studies. Even though this paper is less personal in tone, Campbell's commitment to student learning shines through.

Ilana Margolin, in "A Coterminous Collaborative Learning Model: Interconnectivity of Leadership and Learning," shares Campbell's interest in collaborative learning across different groups of educators. Her study offers a range of perspectives, from novice teachers to superintendents, to a collaborative learning model. Like Scheffel, Margolin engages in an ethnographic study centred on the experiences of learners. Like Campbell, she stands back further from the research participants. Her study focuses on themes about learning in professional communities that emerged from asking people about their experiences in this learning activity.

The final article, "Rocky Road or Clear Sailing? Recent Graduates' Recollections and Reflections of the Doctoral Journey," has the largest group of participants (53) and the least personal form of inquiry (a questionnaire). Nonetheless, Jonathan G. Bayley, Jason Brent Ellis, Carla Reis Abreu-Ellis and E. Kathleen O'Reilly are centrally focussed on understanding learning. They use the survey to gain a thorough understanding of how graduate students experienced the doctoral journey. The answers, which are often quite personal, also convey patterns of experience across individuals and institutions. While there is great power in smallscale studies and personal stories, this article reminds us that large-scale studies can also say much about experience and offer insights into how institutions can contribute to making those experiences more educative.

It is my hope that reading these articles will contribute to your understanding of the teaching and learning experience. By better understanding experience, we become more effective as educators facilitating or constructing experiences for our students.

\section{References}

Dewey, J. (1938). Experience and education. New York: Collier Books.

Schwab, J.J. (1970). The practical: A language for curriculum. School Review, 78, 1-23. 